\title{
Quantitative Analysis of Judicial Voting
}

\author{
Benjamin Alarie and Andrew J. Green
}

\author{
Version Post-print \\ Citation Alarie, Benjamin and Green, Andrew James, Quantitative Analysis of \\ (published version) Judicial Voting (December 19, 2017). \\ http://dx.doi.org/10.2139/ssrn.3090789
}

How to cite TSpace items

Always cite the published version, so the author(s) will receive recognition through services that track citation counts, e.g. Scopus. If you need to cite the page number of the author manuscript from TSpace because you cannot access the published version, then cite the TSpace version in addition to the published version using the permanent URI (handle) found on the record page.

This article was made openly accessible by $U$ of 'T Faculty. Please tell us how this access benefits you. Your story matters. 


\title{
Quantitative Analysis of Judicial Voting
}

\author{
Benjamin Alarie and Andrew Green* \\ Draft: December 19, 2017
}

What makes judges decide cases in particular ways? Empirical work has sought the answer to this question most intensively in judges' political leanings but also not surprisingly in the law as well as in differences in the political and institutional context in which the judges are deciding. What, if anything, makes constitutional decision-making distinctive? At the least, constitutional cases tend to be high stakes disputes, pitting highly motivated interest groups against each other or against the government. The decisions often implicate the basic framework for a society and the basis for what it means to be a citizen.

Because these decisions have such high stakes, the process around how judges make them becomes fraught. Consider the recent constitutional crisis in Venezuela. President Maduro put in place a constituent assembly to re-write the Constitution and extend his powers. He had the backing of the Supreme Court. However, the Venezuelan Congress, led by the opposition party, claimed the current Supreme Court judges were "pirate magistrates named on the fly", being illegally appointed by Maduro's Socialist Party (Ulmer and Ore 2017). The Congress "swore in" 13 judges and 20 substitute judges, setting up a conflict with Maduro and the existing Court and raising concerns about the independence and role of the judiciary. Other countries have had similar struggles. The US, for example, has had its wellknown battles over the structure of the Supreme Court and the identity of its members, from Roosevelt's Court-packing threats related to the decisions about the constitutionality of his New Deal legislation to the recent manoeuverings over filling the vacancy following the death of Justice Scalia.

Constitutional matters have given rise not only to battles over who sits on the bench but also to debates over the role of the court. India, for example, faced questions about the role of its Supreme Court during the Emergency in the mid-1970s. Indira Ghandi's government had declared a state of emergency and had suspended civil rights and stifled political opposition. Once the Emergency ended, the Supreme Court of India adopted a new role in providing access to justice in cases involving civil rights. The Court began permitting individuals to directly petition it where they alleged human rights concerns or government failure (Mate 2015). The result was a rapid rise in the Court's caseload and an increase in the size of the Court (Green and Yoon 2017).

How much do such changes in the structure and role of a court or the identity of its members matter? Do they alter the outcomes of cases at all? Certainly there appears to be a significant variance

\footnotetext{
* Benjamin Alarie is Osler Chair in Business Law, Faculty of Law, University of Toronto and Andrew Green is Associate Professor, Faculty of Law, University of Toronto. We wish to thank David Rybak for excellent research assistance. We also thank David Law, Malcolm Langford and the participants in the Research Methods in Constitutional Law Conference for helpful comments on an earlier draft of the paper.
} 
across countries in how judges decide. One way to think about differences across courts is to consider how political judges are in their voting. At one extreme judges could decide solely based on the law without considering their own personal views at all. At the other judges may be committed to voting completely in accordance with their preferences, regardless of the law. In Figure 1, this degree of commitment to personal views is represented by the horizontal axis, with a court with judges who all vote politically situated towards the left and one whose judges vote more based on the law to the right (Alarie and Green 2017). Courts may also different in how their judges interact. In Figure 1, the vertical axis relates the degree of cooperation among judges on a court, with courts towards the bottom being more cooperative and those towards the top having judges who do not view it as their role to arrive at consensus but instead to find their own solutions.

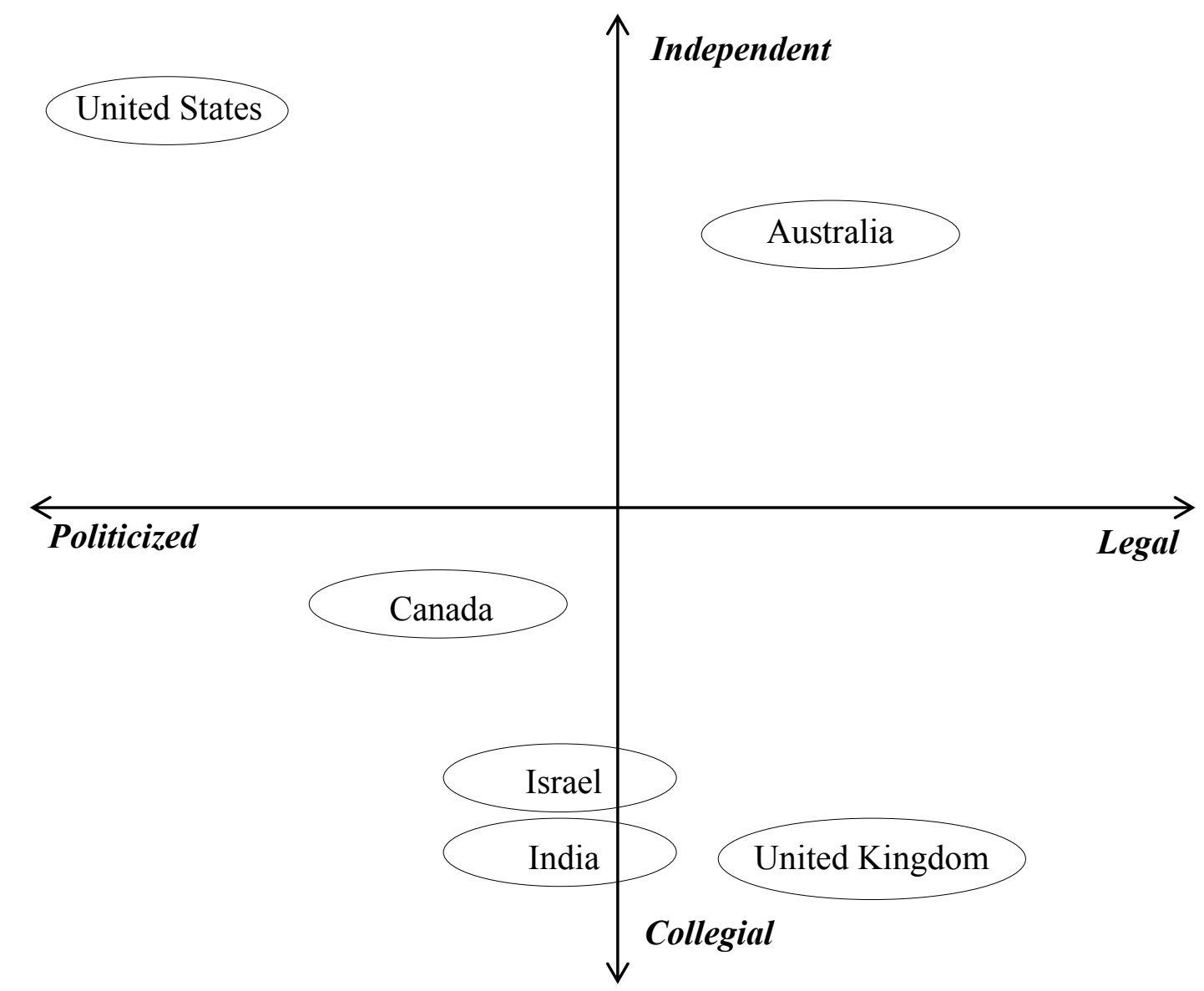

Figure 1 Relative commitment and cooperation of various high courts. The horizontal axis shows the degree to which a court is composed of judges who vote in accordance with their personal preferences as opposed to the law, with courts to the left having judges who are more likely to vote their preferences. The vertical axis represents the degree of cooperation amongst judges on a court, with those towards the bottom being more cooperative. Various high courts are roughly arrayed on this CommitmentCooperation Space using the existing empirical literature. There is variation across high courts, with the US Supreme Court as an outlier based on both its politicization and level of disagreement. (Source: Alarie and Green 2017). 
Of course, no court likely lies at the extremes and most likely shift over time. Further, what counts as 'political' voting or 'cooperative' behaviour is controversial. However, with some broad measurements, courts may be roughly situated relative to each other on this commitment-cooperation space. The degree of commitment may, for example, be measured by some form of connection between the voting of the judge and a measure of their politics (we will discuss various measures of such a connection and their usefulness further below). If we consider all decisions (not just constitutional), the US Supreme Court is clearly to the left of the other courts in Figure 1 on this measure based on existing empirical work. Both the UK House of Lords (the predecessor to the current UK Supreme Court) and the High Court of Australia, on the other hand, have been found to have a much weaker connection between voting and political preferences. If cooperation is measured as the propensity of judges to dissent, again the US is at one extreme with the highest rate of dissent (with over 50 percent of decisions having at least one dissent from 1970 to the early 2000s) and the Supreme Court of India is at the other (with less than five percent of decisions having a dissent over that period) (Alarie and Green 2017). Again, these differences are based on a connection between voting and a measure of political preferences and on dissent rates. On other measures, the relationship between the courts may be quite different. India, for example, could be seen as having a political court considering the extent to which the Court has wrested powers from the executive.

High courts then vary according to these rough measures of outcomes. The aim of empirical research about judicial voting is to examine such differences. How do courts differ in their decisionmaking? Are these differences related to differences in structures? In the law? In the judges themselves? Often decisions are portrayed as the result at least in part of some objective application of the rule of law. However, empirical research seeks additional factors that may influence voting. The goal is not to find the single optimal structure of a court or court system for all countries and for all time. It is hard to look at Figure 1 and argue that every court should be at one particular location on the chart. Designing a court and legal system requires a range of trade-offs. However, by studying the factors that influence how judges vote, we may be able to find ways to make judicial decision-making more just in some sense. ${ }^{1} \mathrm{We}$ may be able to identify features of the court, the law or the surrounding institutions which tend to lead to particular results or patterns. We will then be in a better position to determine if change is needed and, hopefully, identify options for improvement.

What makes empirical research into voting in constitutional cases so difficult is that there are so many potential influences on judges and such tremendous variance across countries. Some countries have

\footnotetext{
${ }^{1}$ Sen argues that we should not seek an ideal set of just institutions but the best we can do is examine feasible existing institutions to determine how to make society more just (Sen 2009).
} 
written constitutions and some do not, and for those that do, the scope of the rights and freedoms varies widely. Some countries have special courts to deal with constitutional matters while others allow lower courts to hear initial applications with appeals going to a generalist high court. At an even more basic level, empirical study of constitutional voting, and on judicial decision-making more generally, is made more challenging by the fact that there is not even a clear, agreed upon theory of how judges make decisions. As we will see, various models of how judges decide have been explored from the legal model (judges follow the law) to the widely used attitudinal and strategic models (examining the degree to which judges follow their personal preferences) and more recently a labour market model and explorations of other dimensions of judicial decisions.

In this chapter we discuss empirical analysis of the various influences on judicial voting in constitutional cases. We begin with a brief discussion of what we are aiming to study - the judge's vote before turning to the judges themselves in Part 2. Does one judge vote differently from another because they are different people, with particular political or world views and certain characteristics such their gender? Studying how a judge's attitudes influence her voting is a long-standing line of inquiry in empirical legal studies and political science. However, not surprisingly, a judge may also care about the law itself. For example, a judge may vote differently in a case involving striking employees if there is a broadly written right to association as opposed to a specific right to strike. What if there is no written constitution at all but instead some unwritten constitutional principles? Part 3 examines some approaches to determining how such differences in constitutional law may influence judges. Part 4 turns to the institutional structure surrounding the judge such as the structure of the court, the nature of the political system, and even the norms of decision-making by the judges themselves. We examine the influence of these institutional differences before considering in Part 5 contextual factors which may shift constitutional decision-making such as war or national security concerns. Our aim is to discuss both how existing analysis has been undertaken and the limitations of such analysis. We end the chapter by pointing to the need for more comparative work.

\section{The Vote}

Before we can talk about analyzing judicial votes, we need to think about what we mean by the vote. It will of course depend on the question that is being asked. Are we seeking to understand whether judges tend to vote in line with their ideology in constitutional cases? Do we want to know whether certain court structures are more likely to favour some parties over others, possibly because of cost or procedural concerns? Are we interested in whether narrowly entrenched rights lead to greater protections of the 
rights holders than broader rights? In each case, we may need to use different measures of a judge's vote or how a court as a whole decides. ${ }^{2}$

In general, the vote will be dependent variable - what we are trying to explain. There are some fairly straightforward ways to specify this variable. If we are considering constitutional cases, one of the most straightforward specifications is whether the judge found the challenged action, decision or legislation to be unconstitutional. Amaral-Garcia et al (2009), for example, examined whether judges on the Portuguese constitutional court voted for or against the constitutionality of legislation to determine if a judge's vote was influenced by the political party that held a majority in parliament at the time it appointed her. Even then, of course, choices had to be made. They examined only decisions in 'preventive' review - when the Court review is requested to review legislation before it is enacted. Similarly, if we are interested in the level of disagreement in constitutional cases (as opposed to the answer given), we may wish to code for whether a judge's decision was with the majority or was a concurrence or dissent.

Relatedly, we may be interested in whether judges in a particular country are activist or not. We will need to determine first what we mean by activist - for example, does it mean a propensity to vote against legislative, majoritarian outcomes? We may, for example, want to code judges' votes for whether they are in favour of the government or not. Such a measure does not necessarily have to have a particular ideological taint, nor does it need to point to whether the level of 'activism' is too high or too low (Choudhry and Hunter 2003). It can merely signal whether or not a judge was willing to find against the government making the decision, whether or not that government has a particular ideological bent. It is broader than merely voting for or against constitutionality, and so may allow study of constitutional cases in comparison to other areas of law. It may be difficult to assess certain types of decisions as in favour or against the government (most obviously where a government is on both sides). Moreover, if the concern is about the conflict between the court and the legislature, cases involving challenges to regulations or government officials may need to be excluded (Choudhry and Hunter 2003). However, it provides a broad measure of the role taken by the court.

There are also more particular questions that can be asked, making more finely tuned dependent variables useful. Epstein et al (2015) studied whether US Supreme Court justices were less likely to depart from precedent in constitutional cases. Using whether or not the Court departed from its own precedent as the dependent variable, they found inconclusive support for the hypothesis that precedent in the constitutional area has a stronger hold on justices than in other areas.

\footnotetext{
${ }^{2}$ For a discussion of how to approach empirical research in the legal context including how to choose across different measures for variables, see Lee Epstein and Andrew Martin, An Introduction to Empirical Legal Research (Oxford: Oxford University Press, 2014).
} 
Much of the empirical work on judicial decision-making, however, has involved trying to determine if and when judges decide in accordance with their personal policy preferences, in contrast often with the 'law' in some sense. We will discuss in the next sections what we may mean by policy preferences of a judge and by the law. However, a related question is how do you know if the outcome (the vote) is ideological in the sense of aligned with a policy position. One direct way is to define an ideological vote as one that a political party would take. Amaral-Garcia et al (2009), for example, in examining whether party politics influenced judicial voting on the Portuguese constitutional court, not only examined votes for or against constitutionality of the legislation, but also used as a dependent variable whether the judge's vote aligned with how the party that appointed them voted in the legislature.

Of course, political parties compromise whereas judges may not have to and so a judge may be consistent with an underlying political position without always deciding in line with a particular political party. Considerable work on US courts, and increasingly some international courts, assigns each vote an ideological direction - in particular, designates votes as either 'liberal' or 'conservative'. A judge's vote could be coded as 'liberal' where it is in favour of a claimant in a civil rights case, or a defendant in a criminal case or a union in a labour case. ${ }^{3}$ Finding such a common measure across areas of law potentially allows for broader connections to be drawn about how a judge behaves in different contexts are judges more likely to vote ideologically in constitutional or non-constitutional cases? In equality or freedom of religion appeals? If we can reliably assign an ideological direction to a vote, the exercise becomes much easier.

However, the classification of votes in particular cases or areas of law can be controversial. While it has been used in other countries such as Canada (for example, in Canada Alarie and Green 2009, Ostberg and Wetstein 2007), there is an issue of the portability, or consistency, of this measure across countries. A 'liberal' vote in the US is relative to its background political and legal context - it is influenced, for example, by the nature of the criminal or constitutional law. The High Court Judicial Database which contains data on a number of different high courts, codes cases as 'pro' or 'con' as opposed to 'liberal' or 'conservative'. Such a neutral label may be more appropriate when comparing across countries. However, even if an ideological connotation for these votes may not fit with how decisions are made in different countries, it can still provide insight into similarities across countries (Alarie and Green 2017; Ostberg and Wetstein 2009; Weinshall et al 2017).

The choice of dependent variable when studying constitutional decisions then depends on the question being asked. The difficulty is not with any of these specifications as such but with what they are taken to measure and how we view them normatively. Is voting in favour of constitutionality more often

\footnotetext{
${ }^{3}$ Epstein and Martin's chapter in this book discusses the various databases that pre-code these variables, though some studies revise these measure (e.g., Epstein, Landes and Posner 2013).
} 
good or bad? Empirical work on its own cannot help with this answer. What it may be able to do is help understand what influences differences in the votes. We turn to the discussion of such influences now and begin with the judge herself.

\section{The Judge}

Does it matter which judge decides a particular case? A long line of empirical work has sought to answer this question. It may seem strange to start with this question rather than, say, whether the particular form of the constitution matters. Yet a judge's vote is such a personal act and this question has dominated so much of the empirical work on judges that beginning this way provides context for thinking about the role of law, institutions and other influences. Part of the difficulty with examining why judges vote as they do has been the lack of a widely accepted theory of judicial motivations, though some advances have been made in recent years. We will start with the narrowest, though most widely studied, explanation for judge's votes - their political preferences.

\section{Political Preferences}

A central, though as we will see not the only, model for thinking it may matter which judge decides a particular case is the attitudinal model. In its simplest form, it views a judge as deciding particular cases based on her own personal views of the best policy outcome in each case (Segal and Spaeth 2002). A judge with 'liberal' policy preferences may be more likely to vote in favour of a plaintiff in a case involving equality rights than a judge with 'conservative' preferences. To the extent the judge has few constraints - such as where the judge is appointed for life, there is no possibility of her decision being appealed to a higher court or she can control the cases that she hears - she is more likely to be influenced by her own policy views. As with the votes, the trick is to identify ideology. The attitudinal model has been developed and tested mainly using the US court system but it has been extended in recent years to other countries. However, like the ideological measures of voting, it is not clear it is transportable to other contexts, at least in its most commonly used form (Alarie and Green 2017; Weinshall et al 2017).

\section{How to Measure Ideology?}

There are two broad ways to measures a judge's ideology (see generally Epstein et al (forthcoming); Fischman and Law 2009). The first looks for factors not directly connected to the decisions by the judge or what Epstein et al (forthcoming) call "exogenous" factors. Many studies have focused on the politics of the party or parties that appointed the judge - such as the party of the appointing President in the US, the party of the appointing Prime Minister in Canada (see, for example, Alarie and Green 2009; Ostberg and 
Wetstein 2007) or the main political parties in Spain (Garoupa et al 2013). It has also been used in other contexts including German and French courts (Honnige 2009), Norway's Supreme Court (Skiple, Grendstad, Shaffer and Waltenburg 2016), the US, UK, Canada and Australia (Alarie and Green 2017) and Portugal (Amaral-Garcia et al 2009)

Using the party of the appointer has some difficulties. Not all those who are in the same party have the same preferences - or even consistent preferences across areas of law - so we cannot assume all judges appointed by these parties have the same preferences (Epstein, Landes and Posner 2013; Epstein et al (forthcoming)). This concern is greater in countries with less polarization and greater variation within parties and across issues. Further, such a measure is not useful for countries where the appointing party is not clear or the power is deliberately separated across parties (Weinshall et al 2017). For example, determining the ideology of the appointer is difficult if not impossible in countries such as the UK (in recent years) and Israel where judges are nominated by a mixed committee or as India where judges are appointed by the chief justice and four senior judges rather than political actors (Alarie and Green 2017; Weinshall et al 2017). In addition there may be conventions or norms or other objectives than ideology that affect appointments and that may constrain or alter choices. Epstein at al (forthcoming) refer to the norm of Senatorial curtesy in the US which constrains Presidential nominations, while in other countries there may be norms about regions or ethnicity or gender that constrain choices (e.g., the recent decision by Prime Minister Trudeau in Canada to seek bilingual candidates for the Supreme Court).

Another influential independent or 'exogenous' source of ideology is newspaper scores that attempt to determine what the perception of the judge was at the time of appointment. These scores were developed in the US by Segal and Cover (Segal and Cover 1989). They are based on content analysis of newspaper editorials identifying the proportion of statements that indicate if a nominee is liberal, conservative or moderate. Scores using similar methodology have been developed for judges of the Supreme Court of Canada (Ostberg and Wetstein 2007) and the High Court of Australia (Weiden 2011). Interestingly unlike in the US where there is quite a close connection between Segal-Cover scores and the party of the appointing president (Epstein et al (forthcoming)), in Canada judges appointed by Conservative Prime Ministers are fairly evenly spread across positive and negative Ostberg-Wetstein scores while Liberal appointees had predominantly positive (liberal) scores (Alarie and Green 2009). This difference points to a potential concern with the translation of one or both of these measures to Canada.

One way to determine ideology then is to look for measures that are prior or 'exogenous' to the vote. The other broad way to identify how a judge's attitudes affect her voting is by examining how she voted. While this method has the benefit of examining her actual decisions, such an inquiry gives rise to concern about tautology - a judge's voting is determined by their voting (Epstein et al (forthcoming)). However, attempts have been made to sort out how to address this issue such as using past votes or votes 
in other areas of law to determine a judge's underlying views before applying them to current votes or votes in a particular area. For example, Wetstein et al (2009) compared liberal voting rates in three areas civil rights, economic and criminal cases - to determine whether judges on the Rehnquist Court in the US and on the Lamer Court in Canada had similar patterns in voting across each of these areas (see also Alarie and Green 2017). They found that for US judges voting liberally (conservatively) in one area was highly correlated with voting liberally (conservatively) in the others while the same relationship did not hold in Canada.

A method that avoids the use of upfront ideological coding of voting was developed by Martin and Quinn (Martin and Quinn 2002). They used decisions where there were dissents to determine which judges tended to vote together, generally assuming a one-dimensional policy space (a line). The method is based on the premise that judges who agree with each other on a case have similar attitudes towards the case and therefore have 'ideal points' on one side of the policy space. Those with whom they disagree lie on the other side. Over a large number of cases, judges can be ordered according to whether they seem closer to some judges as opposed to others. This method does not assign an ideology to a location on the line (that is, it uses agreement or disagreement, without assuming that a particular position is conservative or liberal, for example). Ideology has to be determined by other methods. The Martin-Quinn method has been used widely in the US and has also been applied in other countries including Canada (Alarie and Green (2009)), Portugal and Spain (Hanretty 2012), the UK (Hanretty 2013) and Argentina (Bertomeu et al 2017). As the ideal points do not really provide a reason for the alignment of judges, other information needs to be used to determine what causes the ordering (Epstein et al (forthcoming)).

The more the measure of ideology is tailored for a particular country, the less able it is to provide comparisons across countries. Some use 'liberal' voting rate to compare ideological voting in different countries (Alarie and Green 2017; Wetstein and Ostberg 2009). Courts or judges can be compared on such measures as consistency in voting across areas of law or over time or on how dispersed the voting is on a particular court (Alarie and Green 2017). It has the virtue of comparing voting outcomes, with the rather large caveat that the actual ideological content of the vote as well as its meaning has to take into account the context of the particular court and its legal system - that is, as we discussed above, a liberal voting rate in the US may be different than one in the UK. The same caveat arises with attempts to use the ideology of the appointing party - it may allow comparisons in the strength of the connections to the appointer but not a comparison in ideologies of judges across countries (that is, whether judges in Canada are more conservative than those in Australia). Weinshall et al have taken on the task of attempting to develop a Dynamic Comparative Attitudinal Measure (DCAM) to allow comparison of attitudinal voting across countries (Weinshall et al 2017). It builds on a liberal voting rate but takes into account the ideology of a particular judge relative to her colleagues, the ideological disposition of the case and the 
level of dissent. More work of this kind is needed to provide a secure basis on which to compare across countries.

The key, as with all empirical work, is to try to be hands above the table - that is, if you are making trade-offs, be explicit about them. The ideology or policy preferences of a judge are difficult to pin down. There is no clear definition of what ideology actually means and in any event, it may be multidimensional or at least vary across areas, particularly in countries other than the US (Fischman and Law 2009). It is important to make clear what the study is attempting to find, how it is to be measured and how those two potentially different things are related.

\section{Ideology and Constitutional Cases}

It is hard to separate one factor such as ideology or policy preferences and discuss its impact, without discussing what is being held constant. However, for now it is useful to think just about whether judges decide constitutional cases in accordance with their policy preferences. Constitutional cases may be expected to provide fertile ground for ideological voting: the cases may deal with vague, broad requirements and the issues are highly contested (increasing the potential policy benefits of a decision).

A natural place to start is constitutional cases as a whole - do judges tend to vote in line with their policy preferences in constitutional cases as a group? While we will talk about differences in court structure more in Part 3, we can think of two sets of courts - specialist courts that hear only constitutional cases and generalist courts like the supreme courts in the US, Canada and India. Studies of specialist high courts have tended to use party affiliation as the measure of ideology and find evidence of attitudinal voting. For example, Amaral-Garcia et al 2009 examined the Portuguese constitutional court and found that judges connected with left-wing parties were less likely overall to vote for constitutionality of legislation whereas there was no statistically significant relationship between judges connected with rightwing parties and voting for constitutionality. Further, a judge associated with the party in power is more likely to vote for constitutionality. Similarly judges on the Polish constitutional court were more likely to vote against constitutionality when the judge and the petitioner have the same policy preferences (as measured by party affiliation) (Kantorowicz and Garoupa 2016) as were the French and German constitutional courts when the pivotal judge was appointed by an opposition party (Honnige 2009). For the Spanish constitutional court, judges were 39\% more likely to vote for the party initiating constitutional review (such as challenging the constitutionality of a provision) when the party initiating the review was affiliated with the judge's party at the national level, though other factors also play a role such as regional versus national interests and institutional constraints (such as lack of discretion in some contexts, the civil law tradition, and judicial reputation in front of regular courts) (Garoupa et al 2013). Studies of constitutional courts have also though used ideal point analysis. For example, Hanretty 2012 
examined the Portuguese and Spanish constitutional courts and found that voting could be predicted based on the ideal points of the judges, with their relative positions corresponding to a left-right spectrum.

Sometimes, however, different measures of ideology may lead to conflicting results and point to the desirability of using more than one measure when possible (Fischman and Law 2009). In their study of the Supreme Court of Argentina, for example, Iaryczower et al 2002 looked at the period 1935 to 1997 and at cases that involved published decisions on the constitutionality of government decisions (including laws, and administrative decisions). They found a statistically significant decrease in the probability of a vote for constitutionality where the pivotal justice was not favourable to the party in power, using alignment of the judge with the sitting President (taking into account the politics of the President and Senate that appointed the justice) as the measure of ideology. However, Bertomeu et al 2017 used ideal points to examine judicial voting by the Argentinian Supreme Court in claims with a normative basis in Constitution (political rights, privacy, discrimination, prisoners' and defendant's rights and social right to health). They did not find a strong relationship between ideal points and the ideology of the presidential appointing the judge except during one period - under the Menem government which had expanded the court and had added judges aligned with their interests. Bertomeu et al 2017 argue that these results show that Presidential appointments may not be a useful proxy for judicial ideology. A study that used both may provide a better check on the analysis of the role of ideology in a particular country.

Generalist courts provide an added method to analyze ideological voting in constitutional cases. They hear a wide range of cases, not just constitutional cases, and so provide us with the ability to look not at whether judges vote in line with their preferences in constitutional cases but more broadly as well. It turns out, using the weak comparative tools that we have, there is a high variance across countries in the general level of attitudinal voting by judges. There is clear evidence of attitudinal voting on US courts, though it seems stronger as you proceed up the judicial hierarchy (Epstein, Landes and Posner 2013). The US Supreme Court seems to be the quintessential attitudinal court with judges voting ideologically across areas, regardless of the measure of ideology. ${ }^{4}$ Moreover, there is some evidence that the level of polarization in voting - of Republican-appointed judges differing from Democrat-appointed judges - has increased at least on the Supreme Court in recent years (Devins and Baum 2016). Based on various measures, attitudinal voting has been found beyond the constitutional area on a range of courts as well including the Supreme Court of Canada (Alarie and Green 2009; Ostberg and Wetstein 2007), Norway (Skeple et al 2016), Australia (Smyth 2005), South Africa (Sill and Haynie 2010) and to some extent the UK (Hanretty 2013; Arvind and Stirton 2012). However, most found an apparently lower level of

\footnotetext{
${ }^{4}$ The literature is too vast to cite. For a summary of the empirical literature especially in the US, see Epstein, Landes and Posner 2013.
} 
attitudinal voting than on the US Supreme Court (see Alarie and Green 2017, for a discussion of some of the literature across courts).

As expected, this ideological voting is generally strong in cases involving constitutional issues before generalist courts, often stronger than for other areas of law. One difficulty with the empirical literature analyzing such voting is that it is not always clear which cases are constitutional cases. Many studies collect issues together in a 'civil rights and liberties' category which includes constitutional issues but also statutory matters in some cases. Greater clarity is necessary, although as we will see in Part 3 it becomes complicated as many countries have no written constitution or have additional unwritten constitutional rights. However, with this caveat in mind, studies show that levels of ideological voting in constitutional cases vary across countries. Think of high courts. The US Supreme Court voting most closely aligns with ideological positions in civil liberties cases (see, for example, Edelman et al 2008) and these cases have a lower probability of unanimous decisions (ELP 2013). The evidence for the Supreme Court of Canada is more mixed but with most studies finding that civil rights cases (including cases involving the Canadian Charter of Rights and Freedoms) are at least weakly correlated with ideological voting (Ostberg and Wetstein 2007; Alarie and Green 2009a). However, not all courts showed such attitudinal voting. For the UK House of Lords, for example, the evidence was mixed. Arvind and Stirton 2012 found little evidence of attitudinal voting in human rights claims against the national government (see also generally on a low-level of ideological voting in the UK, Hanretty 2012 and Iaryczower and Katz 2016).

Moving beyond voting on constitutional issues in general, voting can be broken down further into different types of constitutional issues. Are there differences in judges' propensity to vote their preferences across constitutional issues? Do generalized patterns hide important differences? US Supreme Court justices appointed by different Presidents differ, for example, more in First Amendment cases than for privacy or federalism (Epstein, Landes and Posner 2013). In Canada, there was only a weak connection between various measures of judicial ideology and voting in Charter of Rights and Freedoms decisions except in the area of equality where there is less cooperation and much greater correlation with ideology (Alarie and Green 2009a; Ostberg and Wetstein 2007). Depending on the court, the judges' votes in different areas may even be offsetting such as in Canada where judges who vote liberally in equality cases vote conservatively in free speech cases (Ostberg and Wetstein 2007), possibly leading to reduced evidence of attitudinal voting overall in constitutional cases. Differences exist even for federalism cases, with ideology tied to voting for national versus state interests in different countries (Cameron and Park 2009; Collins 2007; Parker 2011).

Even looking across areas of constitutional law might not provide an accurate view, partly because the nature of the underlying case may change. For example, studies have found that the relationship 
between the underlying statute and the judge matter as conservative judges are more likely in some instances to vote against liberal statutes and vice versa (Segal and Spaeth 2002). In freedom of expression cases, Epstein, Parker and Segal (2013) found a strong in-group bias in free speech cases, with liberal justices more supportive of free speech when the speaker is liberal and conservative judges when the speaker is conservative. Further, within a broader category there may be differences. At the US Federal Court level, judicial ideology was not a good predictor of voting in free exercise of religion decisions (Sisk, Heise and Morriss 2004; Heise and Sisk 2012). However, for establishment cases, conservative judges were less likely to support the group invoking the establishment clause (Sisk, Heise and Morriss 2004; Sisk and Heise 2012). It is important then to consider what differences in the area of law or underlying nature of the case may influence what may or may not otherwise look to be ideological voting.

Of course even holding the area of law and the nature of cases constant, a judge's attitudes may change over time particularly if a judge is on the bench for a long time. Judges in different countries spend different times on the bench on average. From the 1970s to the early 2000s, for example, judges on the US Supreme Court were on average on the bench for about 25 years, while on the Supreme Court of India for only about six years (Alarie and Green 2017). It may therefore be important to consider not only an average level of ideological voting but how that voting changes over time. Ensuring consistency in analyzing a judge's voting over time is tricky given changes in who they are on the bench with, in the mix of cases and in the social and political context. Using Martin-Quinn scores, Epstein et al (2007) found that all but four judges on the US Supreme Court shifted in their orientation over the time - some to the left, some right and some back and forth. Similarly in Canada, Alarie and Green (2009) found a mix of a small number of justices of the Supreme Court staying the same and of others drifting left or right or both. It may be important to consider whether to take into account such shifts in the positions of individual judges over time.

Most studies have attempted to examine attitudinal voting within a particular country. There have been few cross-country comparative studies of whether there are differences in how ideological judges are in constitutional cases. A few studies have compared countries in terms of issues like consistency in voting across different issues. For example, as we saw, comparing the US and Canadian Supreme Courts for consistency in liberal voting across civil rights, economic and criminal cases, Wetstein et al found that US Supreme Court judges were quite consistent in their ideological voting, whereas Canadian judges were much less so (Wetstein et al 2009). Alarie and Green 2017 used a similar methodology to examine consistency of voting on high courts in the US, Canada, Australia, the UK and India. Looking at voting in criminal and civil rights matters which might be expected to show the greatest evidence of consistency, the US judges were far and away the most consistent (with a correlation coefficient of 0.93) followed by Australia (0.58), Canada (0.57) and the UK (0.5) with India far behind with essentially no correlation 
(0.03). Similarly, tying country-specific Segal-Cover scores with votes to strike down laws, Weiden found that judges on the US Supreme Court were most likely to be influenced by political views, followed by Australian and then Canada (Weiden 2011).

As we saw, it is difficult to design a cross-country measure that allows direct comparisons. However, Weinshall et al have developed a Dynamic Comparative Attitudinal Measure (DCAM) to allow comparison of attitudinal voting across countries (Weinshall et al 2017). They tested this measure using political rights (such as the right to vote and freedom of assembly) and religious rights (freedom of religion) cases for the US, Canada, India, the Philippines and Israel between 2000 and 2006. They argue these areas of civil and political rights are relatively easy to classify in ideological terms. They coded votes ideologically, although they recognized the terminology was misleading for some countries. Not surprisingly, the US Supreme Court was found to have the most ideological voting, followed by the Canadian, Philippines, Israel and finally the Indian Supreme Court. The results for individual judges in the US were consistent with other measures of ideology.

Again, the fact that on these measures judges appear to vote in constitutional cases in accordance with their policy preferences does not tell us whether such voting is good or bad. The constitution may be drafted in a form that intentionally provides judges with the scope and licence to vote from their own personal perspectives. What we can say is that it looks like in many countries, there appears to be a connection between these measures of policy preferences and voting in constitutional cases. We need to understand more about the differences and the context to evaluate the nature and normative tinge of these differences.

\section{The Judge as Rational Actor}

Assuming judges take into account only policy preferences represents an impoverished view of judges as individuals. Broader approaches to judicial decision-making take into account other preferences of judges. A leading theory, for example, views judges like any other rational actor (Epstein, Landes and Posner 2013). They take into account, and balance, various different factors which may enter their utility functions - that is, they look to satisfy their varied preferences such as preferences for leisure, for money or for a positive reputation. On this view, judges may wish to vote in favour of their policy preferences but there may be trade-offs with other considerations such as how much work it will take to satisfy that policy preference or whether it will hurt or help their chances for promotion or a subsequent job opportunity. Epstein, Landes and Posner (2013) view judges as seeking to maximize their utility across five broad sets of preferences: job satisfaction (ideological and other); reputation and other external forms of satisfaction; leisure; material benefits (such as income); and promotion. 
Take a judge's preference for leisure versus work. The trade-off of work for leisure can influence many different types of decisions a judge may make. An increase in workload has been found to be associated with a decrease in the dissent rate at the US Supreme Court (Epstein, Landes and Posner 2013) and the Australian High Court (Smyth 2004), with Epstein, Landes and Posner (2013) finding that a 10 percent increase in workload is correlated with about a three percent decline in the dissent rate. Other studies, however, have found no or only a weak association between workload and dissent rate in a number of countries (Walker, Epstein and Dixon 1988; Alarie and Green 2017; Songer et al 2011). The workload, and its relationship to the time a judge has at work, may also be related to his ability or willingness to tie a decision into prior decisions through finding and citing case law. Green and Yoon (2017), for example, find that judges on the Supreme Court of India, which decides thousands of cases per year, cite no precedent in about half of its decisions, potentially influencing the path of the common law. Law (2009) argues that the large workload on the Supreme Court of Japan has meant that judges have time to spend on constitutional cases or writing dissents. It may then be necessary to tie voting on constitutional cases in to factors such as workload as they may influence decisions such as whether to dissent, whether to author an opinion and whether to cite precedent.

Depending on how the court is structured, a judge may also care about whether or not she will be promoted to a higher level of court (Epstein, Landes and Posner 2013). Alternatively, constitutional judges in some countries are not appointed for life and are appointed by political actors or players. If so, "when constitutional judges do not have lifetime appointments, as is the case in the traditional Kelsenian constitutional courts, they might want to preserve a close relationship with the party that selected them either for future appointments to the court (if terms are renewable) or elsewhere (if terms are nonrenewable)" (Garoupa et al 2013, at 515). They may even have an opportunity to make money during or after their judicial appointment (Posner 2004).

The labour market theory then attempts to view the judge as an individual in a broader sense beyond just looking at the judge as focused on achieving some policy outcome in her decisions. Such a model allows any number of different preferences to be drawn on - and in fact opens up the whole range of economic research into individual choice. It also, as we will see, ties nicely in with the discussion of institutions in Part 3, as institutions may change the constraints the judge faces - the costs and benefits of any particular type of decision or action. As Posner (2004) notes, "an immediate and important implication of the approach is that judicial behaviour is likely to differ across national legal systems and indeed within a nation's legal systems to the extent that the components of the system ... differ in the incentives and constraints that they impose on judges" (at 1259). 


\section{Identity}

A rational actor theory then can be quite broad, encompassing many different facets of what judges care about. There are, however, other aspects of what it means to be a person that may or may not be completely captured by rational choice theory. If we look beyond straight political leanings of a judge, she may be influenced by other aspects of her identity - such as her religion, gender, race or region of origin.

Take, for example, gender - does it matter that the judge is male or female? Female judges may vote differently for a variety of reasons including information or possibly identity. Again constitutional law would seem to be a prime area to find such a difference. However, the evidence is not clear. Boyd, Epstein and Martin (2010), for example, examine 13 areas of law (including abortion, capital punishment, affirmative action, federalism and race discrimination) and found that only in the case of sex discrimination cases was there an effect, with male judges $10 \%$ less likely to find in favour of the party alleging discrimination (see also Sisk, Heise and Morriss 2004). However, in other countries more of an effect has been found in rights cases. In Canada, female judges were more likely to vote for the claimant in civil rights and liberties cases (Songer and Johnson 2007). In fact, in Canada gender has been found to the single most powerful predictor of judicial decisions in equality/non-discrimination cases, with female judges more likely to reach liberal (pro-claimant) decisions (Ostberg and Wetstein 2004).

Religion may be another important aspect of identity. It may be centrally important to a judge that she is a Catholic or is Jewish or Indigenous. It may influence how she views different policy outcomes or her role as a judge, and may be particularly important in constitutional cases which implicate issues of religion. Weinshall-Margel examined how the religiosity of judges on the Israeli Supreme Court influenced their voting in freedom of religion cases. She differentiated judges into religiously observant and non-observant and found that religiosity was highly correlated with votes in favour of freedom of religion (Weinshall-Margel 2011). Such a connection may change over time. While in the past religion had some predictive value in areas of civil rights and liberties, in more recent years religion had no predictive value for the Supreme Court of Canada (Songer, Johnson and Ostberg 2012) or on the US Federal Courts (Sisk and Heise 2012).

Judges may have a variety of identities that may influence their voting in constitutional cases including their race (e.g., Asian American and Latino judges on US Federal Courts were more likely to decide in favour of claimants in freedom of religion claims (Heise and Sisk 2012)), region of origin (Ontario judges were more likely to vote liberally in civil rights and liberties cases (Songer, Johnson and Ostberg 2012)), background (former law professors were more open to freedom of religion claims (Heise and Sisk 2012)) or even their role as a judge. Schwartz and Murchison (2016) looked at abstract review by the Constitutional Court of Bosnia-Herzegovina. He found that the judges decided differently along 
ethno-national lines, with judges more likely to side with petitioners from the same ethno-national group. The differences could not be explained by party affiliation.

These aspects of identity may be encompassed by the rational actor model (see, for example, Akerlof and Kranton 2000). It may be, for example, that a judge cares about these aspects of her identity because of the impacts of not acting in accordance with that identity on her reputation with groups she cares about (Baum 2008). Alternatively, she may suffer a cost in terms of disapprobation from others or of an internal sense of shame (akin some theories of the development of norms, see MacAdams 1997).

However, these identities may also accord with a non-rational choice framework if certain aspects of an individual are seen as commitments - side-constraints that cannot be violated regardless of the cost (Sen 2002). Imagine, for example, a Catholic judge who is unwilling to vote in favour of abortion rights regardless of the costs it imposes on her such as her reputation or chances for future promotion. The vote is not an expression of a 'preference' in the same way she prefers market solutions or to work less rather than more. More work is needed to understand how judges' identities, as opposed to their policy, influence their voting, which may be particularly important in constitutional cases which implicate such core and contested values.

\section{Other Dimensions and Influences}

Do these factors capture everything that is important to judges? Likely not. There may be other influences on judges. For example, Fischman and Jacobi (2015) argue that for the US Supreme Court in recent years a second dimension of judicial decision-making helped explain several different areas of law including $6^{\text {th }}$ amendment (rights to confront witnesses and their testimony/right to a jury trial) and $4^{\text {th }}$ amendment (right against unreasonable search and seizure) decisions. This second dimension was legalism versus pragmatism with legalism focusing on application of rules with minimal judicial discretion while pragmatism emphasizes the effects of a decision, balancing tests and greater judicial discretion. They argue that voting in those cases was not explained by ideology but by this second dimension.

This issue of other aspects than ideology arises even more strongly in attempts to apply the attitudinal models outside the US. In Canada, for example, the one-dimensional left-right division has not been found to explain voting across multiple issue areas (Wetstein et al 2009; Alarie and Green 2009; Songer, Johnson and Ostberg 2012). There is some evidence of an added dimension in voting in the form of a communitarian-individualist divide but also of a divide across issue areas with some of the most liberal judges in the economic area being the most conservative in criminal law (Songer, Johnson and Ostberg 2012; Alarie and Green 2009). Similarly Arvind and Stirton (2016) built a model that finds that there is polarization on the UK Supreme Court not simply along the left-right axis but in friendliness/sympathy to non-state actors in challenges against the state in public law (violations of 
human rights). Sensitivity to underlying additional dimensions is important to capture differences across courts, although as with most models, the greater complexity makes it harder to actually apply across courts.

These added dimensions may not only influence the outcomes of cases. Consensus may not be explained by ideology alone, or potentially even a preference for leisure. For some judges, ideology may be outweighed by a preference for consensus in some cases (Edelman et al 2012). Hanretty (2013) found that alignment of British Law Lord did not reflect differences in ideology but in propensity to dissent. Such a preference may be able to be encompassed by a rational actor model, although the nature and source of the preference (such as whether it springs from the identity of the judge as a judge) may be important to understanding differences across courts and the impact of different institutional structures.

In addition to focusing on only a few preferences, models of judicial decision-making often assume judges are rational, fully informed, competent decision-makers. However, we know from a range of other areas of study that such assumptions are false and potentially misleading in some contexts. Judges, like all individuals, may make decisions based on unconscious biases, emotions or irrationalities such as anchoring (Rachlinski et al 2011; Rachlinski et al 2015). Moreover, judges may make mistakes and have different abilities. Iaryczower and Katz (2016) studied the British House of Lords using a 'learning model' which combined ideology with an ability measure for judges focusing on the ability to problem-solve and be open-minded. They found judges had differences in ability that were correlated with judicial experience but not with political backgrounds or leanings.

So a more complete picture of how judges decide needs to consider not only ideology and rational choice but other factors. However, any such more detailed portrayal may sacrifice tractability and testability (Epstein et al (forthcoming)). We cannot include everything. Adding more dimensions makes it more difficult to compare across countries, leaving them out makes comparisons even within countries incomplete. And we haven't even gotten to the law or institutions yet!

\section{The Constitution}

Who the judge is then may matter to the outcome of constitutional cases. However, not surprisingly, a judge may be concerned not only (or not at all) with her personal preferences but also with the law. One question we may wish to answer about voting in constitutional cases is whether the constitution itself makes any difference. Suppose a country without a constitution is trying to decide whether to adopt a written constitution and, if so, how broadly to frame it. Or a country has decided to constitutionalize a right to a clean environment but is trying to decide if it should be framed broadly or should lay out the requirements in detail? We may want to know whether the existence of a written constitution or its breadth makes a difference to how judges view particular cases. In one sense it obviously does. If there is 
no right to clean environment, an individual harmed by pollution cannot bring a constitutional claim on that basis. Yet even that is not completely true. A country may have an unwritten constitution or may be able to find a right to a clean environment under other constitutional provisions such as a right to life. How much then does the existence and form of a constitution matter to how judges vote?

In part the answer to such questions lies in how we think judges decide cases. As we saw in the introduction, an alternate model of judicial decision-making is the so-called "legal" model (Segal and Spaeth 2002; Posner 2008; Stephenson 2009). A judge in deciding whether to uphold a strike by a union may vote differently if the constitution includes a specific right to strike versus a right to association versus no mention of such a right at all. Moreover, she may also follow not only the words of a constitution but precedent of the court on how particular provisions are interested. On this view, the judge would not take into account her own view of whether the union should or should not be allowed to strike. She would take the law as she finds it and apply it to the facts.

One way to examine constitutional voting then would be to see how it is tied to the nature of the constitution. Countries provide a rich diversity of constitutional forms. At the most basic level, some countries do not have a written constitution, such as the UK's 'unwritten' constitution which consists of a combination of constitutional conventions, common law principles and several acts of Parliament (McClean 2007). The lack of a constitution may give "flexibility" in adjudication of disputes but may lead to "inconsistent recognition" and application of constitutional rights and other constraints on government (Rothstein 1985). Others have various forms of constitutions from Israel's system of Basic Laws (acts of the legislature which received constitutional status) (Cohen-Eliya 2007) to the United States' single written constitution. Judges may also react differently depending on the age of the constitution. The basis of the United Kingdom's unwritten constitution can trace its beginnings to the signing of the Magna Carta in 1215 (Comparative Constitutions Project 2017). The US Constitution was enacted in 1789 while Poland's constitution in 1997.

Of course, not all constitutions are alike. Elkins, Ginsburg and Melton created the Comparative Constitutions Project (CCP) to provide systematic data to comparative legal scholars. The CCP has compiled information on 190 constitutions including basic information such as year of enactment and length, as well as compiling indices to measure the scope of each constitution, the relative strength of the legislative and executive branches of government, the explicit protections of judicial independence, and the number of rights each constitution explicitly protects (Comparative Constitutions Project 2017). Its CCP Scope Index measures what percentage of 70 different topics are covered by a particular constitution. These topics cover a wide range of issues, from whether or not a central bank receives constitutional status and independence to whether or not social classes or castes are embedded within the constitution (for the full list of topics, see Elkins, Ginsburg and Melton 2009). The median over all 
countries studied was $60 \%$ but the range varied widely from a low of $36 \%$ for Japan to a high of $76 \%$ for Portugal. Of course the degree to which these topics are covered varies as well. One measure is the length of the constitution, with Japan's 4,998 words being dwarfed by Brazil's 64,488 words (Elkins, Ginsburg and Melton 2009). A long and detailed constitution such as Portugal's may provide the constitutional court with many opportunities to be active (Amaral-Garcia et al 2009).

While countries' constitutions vary in scope of topics covered, they also differ in the number distinct rights and freedoms that are enshrined. Elkins et al's Rights Index measures the presence of 117 different rights ranging from constitutional guarantees of academic freedom to social rights such as the right to an adequate or reasonable standard of living (Comparative Constitutions Project 2017a). ${ }^{5}$ The median for all countries surveyed by the CCP is 49 but the number of rights covered varies widely. Israel, for example, has six rights while Portugal enshrines 87 rights.

In considering how judges vote in constitutional cases, then, we would want to know if judges are influenced in their voting by the law including not only the existence of a constitutional right but also the form of the right or freedom at issue. As Spaeth and Segal noted, however, "creating falsifiable hypotheses about precedent and the legal model is not an easy task" (Spaeth and Segal 2001). In part deciding how to test the legal theory depends on how law is seen as interacting with judges. One theory is of partial constraints - that is, the law is so clear in some cases that it determines the outcome but in others (and most that go to the highest level of court), the law is much less clear and it is in these cases that ideology and other factors may play some role in judicial decisions (Epstein, Landes and Posner 2013). Such space for other factors may play a role not only in the substantive outcome but also in the degree of cooperation, such as where a low level of discretion (and weak ideology) for certain cases before the Spanish Constitutional Court lead to greater unanimity (Garoupa et al 2013). In such a case, we would want to know about what types of laws give greater or less space and how the relative weight of law and these other factors is determined (Cameron and Kornhauser 2017).

One place to look to see if the nature of the constitution influences judicial behaviour is judicial decisions following a change in the constitution such as the adoption of a constitution or an amendment to an existing constitution. Weinshall-Margel (2011) tested the influence of the adoption of the 1992 Basic Law in Israel which 'constitutionalized' several fundamental freedoms but not freedom of religion. She found that after the adoption of the Basic Law, judges were less likely to sustain a claim of religious freedom when it conflicted with one of the freedoms in the Basic Law. Both religious and secular judges were less likely to support religious freedom.

\footnotetext{
${ }^{5}$ Comparative Constitutions Project, "Rights Index", online:

$<$ http://www.comparativeconstitutionsproject.org/files/RightsIndex.pdf?6c8912>.
} 
The adoption of a constitution and the form of the constitution may affect not only the outcome but also the level of dissent. Songer and Siripurapu (2009), for example, argued that in the early years after the adoption of the Canadian Charter of Rights and Freedoms, the vague nature of the rights under the Charter, combined with the lack of precedent, resulted in dissension on the Court, although not greater attitudinal voting. In the later post-Charter years, however, this effect was mitigated but the vague language of the text still led to significant dissension on the court with the presence of a constitutional issue being a strong predictor of a dissent.

The plain text then may be important such as whether it includes particular rights or how broad is the language. A related aspect of legal reasoning will also be important - how the judge reads the text. Benesh and Czarnezki 2009 examine whether there are doctrinal approaches that are prior to ideology - in their case whether judges on the US Court of Appeals for the Seventh Circuit use two methods of interpretation (originalism and legislative history) to determine outcomes or whether they adopt these methods strategically in pursuit of particular outcomes. They examined non-unanimous decisions on criminal procedure, civil rights, First Amendment, due process and privacy for whether the ideological direction of the vote (liberal or conservative) was related to the career usage of the judge of one of the two forms of legal interpretation. After controlling for, among other things, ideology (which they measured using career liberalism scores), they found some evidence that the choice of interpretive method is not ideologically neutral.

The text and manner of interpretation may matter to the vote but what about what other judges have decided about the particular issue? Precedent is important, depending on the legal system, given that it may help flesh out rights in a written constitution or may even create new, semi-constitutional rights as with the adoption by the Supreme Court of India of the basic constitutional structure. There are, of course, many reasons why judges may wish to follow precedent - such as that they feel it is the best way to reach the proper outcome or there is a strong norm in favour of it (Hansford and Spriggs 2006), to further their preferred outcome (Niblett and Yoon 2015) or to ensure their own decisions are followed (Landes and Posner 1976).

The literature on precedents is extensive. Many studies have found that judges are at least somewhat constrained by precedent but the evidence is mixed. Lower courts have in general been found to follow precedent (see, for example, Hansford and Spriggs 2006). In examining key cases in constitutional law in the area of the establishment clause, Kritzer and Richards (2003) found that judges tended to take into account the case factors deemed relevant in those precedents, arguing that such key cases create "jurisprudential regimes". Similarly, judges have been found to be less influenced by ideology following a precedent which gave them less discretion in deciding First Amendment cases (Bartels 2009). 
However, not all studies found such a constraining effect, or at least not a strong effect. Spaeth and Segal (1999) examined whether Supreme Court justices who dissented in an opinion later treated that decision as a precedent. They found that sometimes they did treat them as a precedent but more often did not. Moreover, while precedent in the constitutional area may be thought to have a stronger hold on judges, it turns out not to be the case. Epstein et al (2015) did not find support for the hypothesis that precedent in the constitutional area has a stronger hold on justices than in other areas.

Studying the influence on judicial votes needs go beyond the law as written or general statements in precedent. How the law is actually applied in the context of specific fact situations may also be important (Cameron and Kornhauser 2017; Stephenson 2009). Cameron and Kornhauser (2017) argue that there is a need to expand on the attitudinal model by developing models and datasets that identify 'case space', situating cases based on their facts and the law. Kastellec (2010) attempts to bring in case facts in his study of search and seizure cases and confession cases before the US Supreme Court. He used classification trees to attempt to identify patterns in the facts and doctrine that might otherwise be missed. Others have used more traditional forms of analysis to attempt to draw out the influence of case facts in conjunction with the 'law'. Ostberg and Wetstein (2007), for example, found that judicial decisions in right to counsel and search and seizure cases, as well as to some extent equality and free speech cases, are influenced by case characteristics.

More recently, Iaryczower and Katz (2016) built a 'learning model' that attempts more explicitly to join preferences (not just ideology but broader preferences) with case-specific information and applied the model to the UK House of Lords. They argue preferences create a threshold for a vote that must be overcome by the facts and the law for the judge to vote against her preferences, with judges having different thresholds and abilities. They find that the learning model fits the data better than the simple ideological model (correctly predicting about $95 \%$ of the votes) and argue that judges' "decisions are shaped by an evolving balance between information and preferences, which reflects the power of the facts in each case to override ideological considerations" (at 32).

In studying how judges decide constitutional cases, we need to look to legal factors including the existence and form of a right, approaches to interpretation, precedents and the facts. There is much to be done in this area which has so much potential for explaining judicial behaviour but where it is so difficult to design methods to tease out some of these influences. Both the modelling and the data collection become much harder as the case specific information becomes more detailed. Further, it can be difficult to identify clear tests of the influence of the law, particularly given that many high courts choose their own cases, one of the factors we turn to next. 


\section{The Institutions}

Judges then may take into account the constitution as well as their own attitudes towards the appropriate result. They are, however, also embedded in a set of institutions. These institutions include all the formal and informal rules and procedures of the court and legal system itself. These rules may raise or lower the cost or benefit to a judge of taking a particular decision. The institutions also include any norms that the judges follow on a particular court, such as about the acceptability of dissenting or the need to follow precedent. Even more broadly, the court and these norms are entrenched in a political structure that may influence how they view their decisions. We will discuss each of these in turn and how they may impact how judges decide, though of course they are inter-related which makes it difficult to identify the effect of any one institutional feature.

In part this discussion of institutions relates to an important thread in the judicial decision-making literature - the strategic model (Epstein and Knight 1998; Jacobi and Epstein 2010). On this view, a judge takes into account her own preferences for the outcome of the decision but recognizes that the ultimate decision in the case, and perhaps other future cases that she cares about, will depend not only her vote but the reaction to that vote by others such as other judges on her same court, judges in the courts below or above or legislators. The relationship between the judge and these other parties depends on the institutional framework, as we will see, drawing in new institutionalist theories (Clayton and Gillman 1999).

Institutional constraints shape how judges view and meet their preferences (Alarie and Green 2017). However, it is important to recognize that while these institutional features may influence how a judge decides, at the same time judges have the ability to alter some of these institutions (Weingast 2002). A prime example is appointments to the Supreme Court of India. Appointments are effectively made by a group composed of the Chief Judges and the four most senior judges. Such a process may make a direct link to political parties weaker but it could potentially raise other concerns such as about diversity on the Court. However, the judges themselves set up this structure for appointments. We need a better understanding of this two-way relationship in how institutions and norms arise and develop and the effect they have on judges (Arvind and Stirton 2012).

\section{The Court System}

The most obvious place to start to think about institutional factors that may influence how judges vote is the court structure itself. As Garoupa et al (2013) note, "[t]he design of constitutional review involves critical choices, including centralization, standing, court size, the judicial appointment mechanism, and the extension of constitutional review (e.g., abstract versus concrete review)" (at 514). Table 1 shows some of these choices across several high courts. Such choices may raise the costs or benefits of certain 
types of voting, including through altering the relationship of the individual judge with her fellow judges or other parties.

Table 1: Institutional Differences Across Various High Courts (Various Years)

\begin{tabular}{|c|c|c|c|c|c|c|c|}
\hline & Canada & India & Israel & Japan & Portugal & Spain & US \\
\hline $\begin{array}{l}\text { Generalist or } \\
\text { Constitutional }\end{array}$ & Generalist & Generalist & Generalist & Generalist & Cons & Cons & Generalist \\
\hline $\begin{array}{r}\text { Civil or } \\
\text { Common Law }\end{array}$ & Common & Common & Common & Civil & Civil & Civil & Common \\
\hline $\begin{array}{r}\text { Number of } \\
\text { Judges }\end{array}$ & 9 & 31 & $9-15$ & 15 & 13 & 12 & 9 \\
\hline Panel Size(s) & $5,7,9$ & $\begin{array}{l}\text { Mostly } 2 \\
\text { or } 3\end{array}$ & Most 5 & $\begin{array}{l}5, \text { major } \\
\text { cases by } 15\end{array}$ & $\begin{array}{l}\text { En banc } \\
\text { and panels } \\
\text { of } 5\end{array}$ & $\begin{array}{l}\text { En banc } \\
\text { and } 3\end{array}$ & En banc \\
\hline $\begin{array}{r}\text { Cases Heard } \\
\text { Per Year } \\
\text { (approx.) }\end{array}$ & 90 & 7,500 & 1,500 & 12,000 & 1,500 & 350 & 90 \\
\hline $\begin{array}{l}\text { Docket } \\
\text { Control }\end{array}$ & $\begin{array}{l}\text { About } \\
80 \%\end{array}$ & Partial & Weak & $\begin{array}{l}\text { Mostly } \\
\text { Mandatory }\end{array}$ & Very weak & $\begin{array}{l}\text { Some, but } \\
\text { none for } \\
\text { abstract } \\
\text { review }\end{array}$ & $\begin{array}{l}\text { Almost } \\
\text { Full }\end{array}$ \\
\hline Appointment & Executive & $\begin{array}{l}\text { Chief } \\
\text { Justice } \\
\text { and } 4 \\
\text { most } \\
\text { senior } \\
\text { judges }\end{array}$ & $\begin{array}{l}\text { Executive } \\
\text { and } \\
\text { special } \\
\text { committee }\end{array}$ & $\begin{array}{l}\text { Legislature, } \\
\text { executive } \\
\text { and } \\
\text { 'Judicial } \\
\text { Council' }\end{array}$ & $\begin{array}{l}\text { Legislature } \\
\text { (10) and } \\
\text { judges (3) }\end{array}$ & $\begin{array}{l}\text { Executive } \\
\text { and } \\
\text { special } \\
\text { committee }\end{array}$ & $\begin{array}{l}\text { President } \\
\text { with } \\
\text { consent of } \\
\text { Senate }\end{array}$ \\
\hline
\end{tabular}

Sources: Alarie and Green 2017; Law 2015; Amaral-Garcia et al 2009; Constitutional Tribunal of Portugal (www.tribunalconstitucional.pt); Garoupa et al 2013; Spanish Constitutional Tribunal Annual Report 2016 Table 17 (http://www.tribunalconstitucional.es/en/memorias/Estadisticas/ESTADISTICAS2016.pdf (excludes inadmissibility and termination orders - with such orders, the total reaches 7,500).

Most obviously, judges are imbedded in different types of legal system - either common law or civil law. Common law and civil law courts differ in their attitude towards precedents. However, they may also be related to different approaches of the court to constitutional issues. The civil law conception of adjudication as 'a narrowly circumscribed deductive endeavour" tends to make invalidation of legislation on constitutional grounds 'inherently more political' than common law adjudication and may deter civil law judges from expansive constitutional interpretation (Rosenfeld 2004). Common law judges, on the other hand, may rely on the text but also lean heavily on doctrine and precedent, potentially providing greater scope and licence for ideological voting.

Beyond the background legal regime, choices have to be made about the framework for the Court's activities. As we have noted, some countries rely on generalist courts to decide constitutional 
issues, while others have set up specialized constitutional courts. Separate courts may allow greater scope for expertise, aiding in the quality of legal decisions given the increasingly complex realm of constitutional law. Conversely such specialization may lead to the law becoming out of touch or arcane, with judges more likely to impose their views of the correct policy (Damle 2005). Further, separate constitutional courts may view themselves as 'quasi-legislative' and so see a greater need for and acceptance of some politicization (Carroll and Tiede 2011). In part this distinction is related to the powers provided to the court. Some courts, specialist constitutional courts but also some generalist high courts such as in Canada, have the power to review questions about the constitutionality of legislation before it is enacted (or in absence of a specific dispute) whereas others such as in the US require specific disputes. In the former, encompassing abstract as opposed to concrete review, judges may be seen as more explicitly addressing policy questions about the statute (Cameron and Kornhauser 2017). A number of studies have examined the influence of ideology in the context of abstract review (see, for example, Amaral-Garcia et al (2009) studying the Portuguese court's decisions in preventive review (before legislation is enacted)).

Relatedly, courts have differing ability to hear constitutional cases, and to choose the constitutional cases that they hear. Some courts possess exclusive jurisdiction to hear constitutional cases whereas for others, constitutional cases must first proceed through lower courts. The impact of a hierarchy of courts hearing a particular case has been extensively studied in the US. Epstein, Landes and Posner (2013) examined the US Federal Court and found that ideology plays an increasingly important role at higher levels of courts, in part because lower courts may be constrained by the possibility of appeal. High courts may be most open for ideological voting given the lack of a further appeal (Segal and Spaeth 2002).

Moreover, whether a court gets to choose the cases it hears has important implications for both the analysis of judicial decisions and to how judges make decisions. Some courts must hear a wide range of cases such as the Israeli Supreme Court (Eisenberg et al (2011)), which has original jurisdiction over certain disputes, or the Supreme Court of Japan which has had little discretion over its caseload in the past (Law (2009)). Having to hear cases may influence the pattern of outcomes in those cases. Eisenberg et al (2011) examined mandatory and discretionary cases before the Supreme Court of Israel. They found that the Court accepted few discretionary cases and those that it did accept, it reversed a much higher rate than discretionary cases. Other high courts such as in the Australia, New Zealand and Australia have complete control over the cases they hear. In between are courts such as the Canadian Supreme Court, which chooses most cases it hears but about $20 \%$ of its docket is composed of criminal cases it must hear (Alarie and Green 2017). The ability for a court to choose its own caseload creates enormous concerns for the study of such courts. There is a selection effect, which may bias the results of any studies that try to draw conclusions such as about the nature of ideological voting on a particular court. 
Considerable effort has gone into trying to determine how courts choose the cases they hear. They may choose fewer cases to reduce their workload, or may key into signals of which appeals are particularly important or may choose cases to enable them to further their policy preferences. For the US Supreme Court, for example, ideology does appear to play a role in the selection of cases though possibly only in those cases that should not be either clearly accepted for review or rejected (Epstein et al 2012; the literature on case selection at the US Supreme Court is large, see also, for example, Cordray and Cordray 2008 and Black and Boyd 2012). For other courts, however, there is not a clear connection to ideology. Iaryczower and Katz (2016) examined the cases chosen by the UK House of Lords and the backgrounds of the judges and found that the cases were not correlated with the politics of the judges. The impact of ideology on the selection of cases may depend on other structural elements of the particular court. The Supreme Court of Canada has been found to have a low level of connection between ideology of the judges and the cases selected, which may in part be due to the fact that unlike in the US where appeals are heard en banc, the fact that the Supreme Court of Canada hears appeals in panels makes it more difficult for a judge deciding whether the Court should hear a case to predict the outcome at the actual hearing (Flemming and Kurtz 2002; Alarie and Green 2017).

As we have seen, a central element that has been studied in the relationship between the structure of the court system and how judges make decisions is who actually hears the particular decision - how do judges get appointed and which judges hear a particular decision? The appointment processes for judges also vary widely across countries. In some countries, the choice is essentially made by the executive branch (such as Australia, Canada and formerly the UK) or by the judiciary (India). In the US, the executive and the legislature are involved in the appointment process. Other countries have developed committees of multiple stakeholders and political parties that are involved in the choice (such as Israel and more recently the UK) (Alarie and Green 2017). Honnige (2009) points out the variation in appointment processes across constitutional courts in Europe, with various combinations of the executive, the upper and lower houses and the judiciary making the nominations.

Attempts have been made to trace the choice of appointment process to the political nature of voting on a particular court. Do less political processes result in less political courts? As we have seen, the US Supreme Court with its highly political process has been found to have high levels of ideological voting. It has been difficult, however, to compare directly across courts to determine if the level of ideological voting is connected to the nature of the appointments process. Honnige (2009) examined whether there was a connection between the different appointment processes for constitutional courts and voting, looking at success of challenges in abstract reviews. He found that despite the different mechanisms, a connection existed between the party nominating the judge and success of challenging party, whereby if the pivotal judge was chosen by current governing party, the challenger less likely to 
win. As Garoupa et al (2013), at 514 note "Constitutional judges (as opposed to traditional career judges in Continental Europe) are directly appointed by political actors or by bodies with relevant political presence and therefore are likely to be exposed to heavy influence by political parties." Little work has been done on the impact of the use of committees on ideological voting on courts, or of appointments by the judiciary itself. The Israeli Supreme Court, which is appointed by committee, has some polarized voting (Weinshall-Margel 2011). In India the Supreme Court, where new members are appointed by the Chief Justice and the four most senior members of the Court, judges seem to have little consistency in liberal voting rates across areas of law, though there may be other effects of judicial self-replication such as on willingness to dissent (Alarie and Green 2017).

The impact of political appointment will depend also on the background political system. In Canada, for example, one of the reasons for the lower levels of ideological voting is that while the Prime Minister has the power to appoint judges, the political parties have tended to be fairly similar leading to a lower variation of preferences (Alarie and Green 2009; Ostberg and Wetstein 2007). Moreover, the types of judges on a court may change over time as the appointment process changes. Carroll and Tiede (2011) examined the Chilean Constitutional Tribunal before and after changes to the appointment structure to study whether they had an impact on the rate at which legislation was deemed unconstitutional. They found judges appointed by elected officials were more likely to find laws unconstitutional relative to those appointed by the Supreme Court itself. Similarly, Iaryczower and Katz (2016) examine the UK House of Lords and find that there has been an increase in the openness of judges to alter their opinions to case-specific information (as opposed to ideology), which they attribute in part to the decline of politics and increase in merit in appointments.

Relatedly, courts differ in the number of judges on the court as well as who hears individual appeals. The variation is great even across high courts. The US and Canadian Supreme Court have nine judges each, but the US Supreme Court hears almost all their cases en banc while the Supreme Court of Canada hears appeals in panels of five, seven or nine judges with the Chief Justice choosing how many judges and which judges hear particular appeals. The Supreme Court of India, on the other hand, has 31 judges and hears decisions mainly in panels of two judges (Green and Yoon 2017). Panel selection can have an important effect on the outcome of the appeal not only because of the straight trade-off of judges with different political preferences but also because of panel effects. The way judges decide has been found to be influenced by who else is on the panel, possibly due to amplification of preferences when similar judges are together or the dampening effects of others on the panel with different views (Sunstein et al 2006). In the US, for example, Sunstein et al (2006) traced the effects of different combinations of Republican appointees and Democratic appointees sitting together in panels on the US federal courts of appeal and found that the difference between homogenous and mixed panels was stark. It is not only 
political preferences that matter but also other personal characteristics such as gender and race (Kastellac 2013; Boyd, Epstein and Martin 2010). Few studies have looked beyond the US context but those that have have found similar, though weaker, effects (see, for example, Eisenberg et al 2012; Robertson 1998; Alarie and Green 2017). However, the existence of such panel effects is not uncontroversial. Fischman (2015) found that many of the results on panel effects can be explained by a norm of consensus rather than ideology. Moreover, while the Chief Justice may be granted the power to choose the number and composition of panels, they may choose less for ideological reasons and more for efficiency reasons, such as to ensure optimal use of the court's resources (Alarie, Green and Iacobucci 2015).

These court structure issues may be interrelated and have significant implications for judicial decision-making. They may, for instance, affect the caseload of the court which can vary widely. At the high court level, the US and Canadian Supreme Courts have generally heard less than 100 cases per year in recent years while the Supreme Courts of Argentina, India and Japan hear thousands of cases per year (Bertomeu et al 2017; Robinson 2013; Law 2009). India is an interesting example of the interrelation of structural elements and decision-making. Following the Emergency during which Indira Ghandi suspended civil rights, the Supreme Court of India expanded access to the courts to allow individuals to directly petition to the Supreme Court to address government failure or human rights issues (Robinson 2013; Green and Yoon 2017). In part, the Court may have felt the need to expand its jurisdiction to overcome the weakness in other institutions including lower courts (Robinson 2013). The result was a vast expansion in the caseload of the Court. The Court adapted in a number of ways, including by expanding the number of judges to 31 and dropping the panel size from mainly three and five judges down to two judges. The increased caseload and change in the court structure is associated with a low level of citation of precedent by the Court in most cases, with the Court seeming to have to triage its caseload by investing time and resources into a low number of cases and little effort into others (Green and Yoon 2017). Moreover, constitutional cases must be heard by panels of five judges but there are few panels of five recently (Robinson 2013), in part possibly because the Court can choose which cases are deemed constitutional. As noted above, the caseload may also influence the willingness of judges to dissent (Epstein, Landes and Posner 2013). Perhaps not coincidentally, the Indian Supreme Court has an extremely low level of dissenting opinions (Green and Yoon 2017).

Thus a range of choices about how to structure the court system may be related to how judges vote from the background regime of civil versus the common law and the choice of a generalist versus constitutional court to issues such as how to appoint judges and who hears an appeal. There are a range of other structural factors beyond those we have discussed such as whether the judges deliberate before the oral hearing and conference meetings (as in France and other European courts) or after (as in the US and Canada) (Cohen 2014), how the author of an opinion is chosen, whether there are law clerks and how 
open the court is to interventions by non-parties. An interesting question relates to the formation and adaptation of these rules. As these rules and structures may influence votes, Amaral-Garia et al (2009) argue that constitution drafters often set up the court that will review them so the design of the court may protect their interests. Similarly, Cohen argues that the language chosen as the official language of a multinational effects can have an important effect on its staffing, rules and possibly even substantive outcomes (Cohen 2016). She refers to the use of French as the official language on Court of Justice of the European Union, the European Court of Human Rights and the International Court of Justice, the "French Capture" (Cohen 2016, at 499). More work is needed on the origin and evolution of court structures, along with the political economy.

\section{Norms}

Formal rules may then influence how judges vote. However, courts are also structured by norms. These norms may sway judges towards greater or less ideological voting or higher or lower levels of cooperation and dissent. Judges may follow norms because they feel guilt when they do not or because they fear sanctions (such as to a worsening of their reputation) from others such as their fellow judges (McAdams 1997). They can be key to understanding why judges on otherwise similar-looking courts may be behaving differently. As with other influences, the difficulty is teasing out when a norm is actually operating.

One of the most study norms is the norm of consensus. Levels of cooperation and dissent on courts may be related to the existence or lack of a norm of consensus. Dissent rates vary widely across high courts with the US at the high end with over half of cases having at least one dissent and India at the low end at less than five percent (Alarie and Green 2017). How can you explain such variance? In part it may be due to different preferences concerning leisure (Epstein, Landes and Posner 2013), particularly given the widely different caseloads of high courts. It could also be due to cases which implicate greater or lesser ideological disagreement. There is some evidence from courts around the world that dissent rates are related to level of ideological disagreement (see, for example, Songer, Szmer and Johnson 2011; Narayan and Smyth 2007).

Edelman et al (2012) examine consensus on the US Supreme Court to see if it is related to ideology - that is, consensus exists where ideology does not matter (see also Walker, Epstein and Dixon 1988). They find in fact that other factors are at play including possibly a preference for consensus. Similarly the UK House of Lords has a strong norm of consensus which leads judges to avoid dissenting if possible (Arvind and Stirton 2012; Hanretty 2012) and voting in asylum cases at the US $9^{\text {th }}$ circuit courts may be better explained by a norm of consensus than by ideological voting (Fischman 2011). 
Norms may be related to more formal rules and structures. For example, the power of a norm of consensus may be related to the size of the panels on a court. Smaller panels may give rise to or at least enhance such norms as a judge may be less willing to dissent on small panels where the chance of upsetting a fellow judge may be larger (Weinshall et al 2017). Further, the background tradition may matter. Garoupa et al (2013) argue that on the Spanish Constitutional Court where civil law tradition favours consensus, judges may favour not dissenting in order to maintain legitimacy. These norms may also be related to such factors as the strength and powers of the Chief Justice who may be able to foster greater levels of consensus (Alarie and Green 2017).

Norms then may influence how judges vote. They may not only influence whether a judge dissents but a wide range of other issues such as the level of ideological voting that is acceptable, the need to follow precedent and whether merit or political allegiance is an appropriate basis for nominating a judge. They may lead judges "to believe that their position imposes upon them to act in accordance with particular expectations and responsibilities" (Clayton and Gillman 1999, at 4). The development of these norms and their relationship to formal rules is understudied given their importance. Is it possible to change norms on a court? How can it be brought about? When will more formal rules overcome a longstanding norm? Such questions are important to thinking about reforming courts.

\section{Beyond the Court}

Judges may take account not only what their fellow judges think or prefer but other institutions such as the legislature. A judge may, for example vote not for her ideal policy but for a policy that she thinks the legislature will not try to subvert (Epstein and Knight 1998). The extent and nature of such strategic behaviour, if it exists, will depend on the underlying political and constitutional framework, such as the ability of the legislature or executive to react adversely to court decisions. Countries differ on basic levels such whether the country is democratic or not; whether it is a parliamentary system, a presidential republic or a mixed system; whether the country has a unicameral or bicameral legislature; and whether the country is unitary or a federal state. Presidential systems may have a structural commitment to the separation of powers and distinct legislative and executive branches, whereas Parliamentary systems have a greater fusion of the legislative and executive branches of government (Albert 2010). Moreover, some countries have stronger legislatures or executives under the country's constitution. The Comparative Constitutions Project ranks countries according to a Legislative Power Index and an Executive Power Index (Elkins et al 2009; Elkins et al 2012).

These differences may make it more or less likely that a court will exercise its powers to invalidate legislation or take a position contrary to the ruling party. Governments have a variety of means to retaliate for judicial decisions. Perhaps the most benign may be to enact legislation that counteracts the 
decision. Epstein, Knight and Martin argue that in the US context it may look as though judges would not take into account the concerns of the legislature in constitutional matters as the legislature cannot respond without a constitutional amendment which is costly and difficult. However, they argue the Court might still have regard to legislative preferences out of a fear of a loss of legitimacy. Such a result of course depends at least in part on the structure of the constitution. Both Canada and Israel, for example, have override clauses which allow the legislature to override decisions of the courts relating to certain rights as long as it does so explicitly. Such an override is still potentially costly politically but less so likely than a full constitutional amendment. Such clauses may provide the court with greater confidence when reviewing impugned legislation (Weinrib 2016).

Alternatively, governments may be able to take even stronger action. Many courts have been either threatened with or subject to court packing schemes or other retaliatory actions. The Argentinian Supreme Court, for example, was expanded from five to nine judges in 1990 as Court was packed with those favourable to President Menem. Some of these judges were later removed in 2003 under Kirchner who then instituted a more transparent appointment process, and reduced the number of judges back to five (Bertomeu et al 2017). Courts may react to such threats by altering their voting or even by not deciding some issues to reduce the probability of conflict (Epstein et al 2002).

Voting in constitutional cases has been found to align with party politics. In their study of the Portuguese Constitutional Court, Amaral-Garcia et al (2009) looked at whether the party in power matters to judges and found that it does for judges appointed by parties on the left (socialists and communists) though not the right. Similarly, Iaryczower et al 2002 examined the alignment of judges on the Argentinian Supreme Court with the sitting President, taking into account the politics of the President and Senate that appointed the justice. They found that there is a statistically significant decrease in the probability of a vote for constitutionality where the pivotal justice is not favourable to the party in power.

However, such results may solely be the result of alignment of interests rather than judges altering their votes to take into account the preferences of elected officials. Iaryczower et al 2002 therefore also look at whether judges were more or less willing to strike down legal rules under different levels of presidential control of Congress, taking such control as a measure of the ability to retaliate against the courts. They find judges were more likely to strike down legislation if the president did not have control (i.e., was less able to retaliate), comparing democratic and military rule.

Understanding the relationship between judges and elected officials requires a measure of each of their preferences. Iaryczower et al 2002 use the willingness of the court to overturn legislation. In the US, judicial common space scores have been developed to study the relative policy preferences of the courts and elected officials such as the President, Congress or committees (Epstein et al 2007). It uses Martin-Quinn ideal points for judges with scores for voting patterns for various elected officials, 
assuming a one-dimensional policy space. It provides a means to attempt to take account of strategic behaviour by courts (Epstein et al (forthcoming)).

That judges may engage in strategic behaviour seems reasonable. Courts vary widely in their level of independence. The Comparative Constitutions Project has developed an independence ranking for courts, taking into account such factors as whether the constitution contains an explicit statement of judicial independence, whether the constitution provides for lifetime appointments of judges, whether and how removal is permitted and whether there is protection of judicial salaries (Melton and Ginsburg 2014). These factors may be related to the willingness of a court to act as a constitutional check on the legislature, though as we have seen courts may be attuned to the preferences of the legislature even in absence of a realistic threat to the court itself.

\section{The Times}

So far we have talked about courts in one sense atemporally - that is, we have talked about judges themselves, the law and, to a lesser extent, the institutions as if their relationship was stable regardless of what was going on around them. Constitutional adjudication, however, arises often at times of great change, socially or politically. Wars, terrorism, changing perceptions of rights of individuals may all lead to constitutional challenges before the court. Do the times matter? Can we see patterns in the influence on judicial voting of societal changes?

Take times of war, for example. Do the courts seek to act as a check on government during such times or are they more deferential, providing more room for the government to action? Schorpp (2011) examined decisions of the high courts of the US, Canada and the UK during times of war from 1949 to 2008. She found that judges were less likely to resolve constitutional cases in a manner favourable to the government than non-constitutional cases. However, war and national security cases were more likely to be decided for government. She also found that high casualty rates and government approval ratings were associated with decisions favourable to the government, except in the UK. She argues that judges see the possibility that the government might take on broader powers during wartime and respond with heightened scrutiny. There were differences across countries. The UK House of Lords and the Supreme Court of Canada were more likely to find in favour of the government than the US Supreme Court.

Epstein et al (2005), however, found a different pattern in looking at the US Supreme Court's decisions on rights and liberties over the period 1941 to 2001, whether during times of crisis or not. They found the Court was more likely to curtail rights and liberties during times of crisis and war. However, this effect was only observed for cases unrelated to war, with no evidence that cases directly related to war were affected. Other studies of the US courts found no effect of war or crisis. Clark (2006) found there US Supreme Court was no more deferential to the executive encroaching on the separation of 
powers during wartime (though became much more conservative in criminal matters). Further there was no evidence of a "9/11 Effect" for Muslim litigants (that is, no statistically significant decline in success) in freedom of religion cases before the US Federal Courts (Sisk and Heise 2012).

Hofnung and Margel (2010) examine terror-related cases litigated at the Israeli High Court of Justice between 2000 and 2008. They find that the High Court of Justice does play a role in protecting human rights but does not do so overtly. Instead the Court uses implicit means of preventing harmful executive action. To examine this issue, they coded cases not only for the outcome but for factual variables such as the legal arguments and the severity of the threat to security. To understand the broad range of Court action, they had to move beyond a dichotomous variable indicating whether the petitioner won or not to include partial success such as where the Court finds the human rights violation but only gives partial relief or where it acknowledges the validity of the claim but rejects the petition. In the latter case, it avoids a binding decision but sends a message, generally with some form of negotiated settlement. Hofnung and Margel term such decisions latent intervention, found by looking at the entire process rather than only the outcome. They find that if a decision is made after a terror attack or during military operations, it is much less likely to overtly support human rights and there is a reduced probability of overt intervention as opposed to latent intervention. They view latent intervention as a less politically difficult option that allows them to still protect human rights.

Other factors may impact justices. Judges may be swayed, for example, by either good or bad economic times (Brennan, Epstein and Staudt 2009; Epstein, Landes and Posner 2013). More generally, judges' voting may be influenced by public opinion and changing values. Ostberg and Wetstein (2017), for example, examined a range of decisions by the Supreme Court of Canada including equality and discrimination cases to determine whether the Court had shifted in lining with shifting societal values. They find that the justice's values did evolve with the times. The evidence in the US is mixed, with some finding a relationship with public opinion though actual causation is less clear (See Epstein, Landes and Posner 2013 for a review of the literature). In her study of high courts in wartime, Schorpp (2011) found that the UK House of Lords was less susceptible to public opinion than the US Supreme Court.

\section{Understanding Voting in Constitutional Cases}

A wide variety of factors may then influence a judge's decisions. Understanding how judges vote is central to improving the fairness and justice of the legal system. Empirical study is an important tool to develop this understanding. It can aid in discovering the ties between the institutional and legal constraints on judges and, for example, whether they decide primarily in line with their political preferences and the extent to which they deliberate on important issues. It can bring to light the effect of 
different methods of appointing judges, of accepting evidence, of structuring a high court or a court system and of constructing a constitution.

As we noted in the introduction, it is not a matter of trying to find the ideal court for all countries. However, there is much to be learned from the broad range of structures and contexts around the world that can aid in improving existing courts. Part of the difficulty is finding a simple, parsimonious model that allows useful comparisons both within and across courts. Different social and political contexts have resulted in different trade-offs in laws and court structures. What is needed is a clear sense of what the underlying commonalities are that allow an understanding of the choices that are made. The rational choice model/labour market model provides a strong unifying theme around individual choice but may miss out on some aspects of judges such as their identity. Other attempts have been made at joining models, such as the learning model of Iaryczower and Shum which attempts to combine the attitudes and the law by seeing policy preferences as a threshold which judges will vote against if the law and facts are sufficiently strong (Iaryczower and Shum 2012). It builds on the ideological story to bring in information about the case (see also Cameron and Kornhauser 2017).

Considerable promise for improving legal systems using empirical studies rests in examining how different courts functions. If we want to make legal systems more just, we need to examine how different courts work in practice (Sen 2009). Empirical work cannot provide the normative answer directly but it can help differentiate across options and perhaps allow sorting out choices which are outside the range that lead to solutions that on all accounts would be deemed unacceptable. To do so, empirical work needs to be better able to understand the conditions that make courts work in some countries and not in others, what conditions underlie the choice of institutions and the balance that is inherent in a system. It is a complex task and will need to build on the impressive work already done within countries but it is an essential one - the next step in the move towards more just institutions.

\section{References}

Akerlof, George A. and Rachel E. Kranton. 2000. "Economics and Identity." 115(3) Quarterly Journal of Economics 715 .

Alarie, Benjamin and Andrew Green. 2009. "Policy Preference Change and Appointments to the Supreme Court of Canada." 47 Osgoode Hall Law Journal 1.

Alarie, Benjamin and Andrew Green. 2009a. "Charter Decisions in the McLachlin Era: Consensus and Ideology at the Supreme Court of Canada." 47 Supreme Court Law Review (2d) 475. 
Alarie, Benjamin, Andrew Green and Ed Iacobucci. 2015. "Panel Selection on High Courts." 65(4) University of Toronto Law Journal 335.

Alarie, Benjamin and Andrew Green. 2017. Commitment and Cooperation on High Courts: A CrossCountry Examination of Institutional Constraints on Judges. New York: Oxford University Press.

Amaral-Garcia, Sofia, Nuno Garoupa and Veronica Grembi. 2009. "Judicial Independence and Party Politics in Kelsenian Constitutional Courts: The Case of Portugal." 6(2) J. Empirical Legal Studies 381.

Arvind, TT and Lindsay Stirton. 2016. "Legal Ideology, Legal Doctrine and the UK's Top Judges." Public Law 418.

Bartels, Brandon L. 2009. "The Constraining Capacity of Legal Doctrine on the US Supreme Court.” 103 American Political Science Review 474.

Baum, Lawrence. 2008. Judges and Their Audiences. Princeton, NJ: Princeton University Press.

Benesh, Sara C. and Jason J. Czarnezki. 2009. "The Ideology of Legal Interpretation." 29 Wash. U. Journal of Law and Policy 113.

Bertomeu, Juan Gonzalez, Lucia Dalla Pellegrina and Nuno Garoupa. 2017. "Estimating Judicial Ideal Points in Latin America: The Case of Argentina." 13(1) Review of Law and Economics.

Black, Ryan C. and Christina L. Boyd. 2012. "Selecting the Select Few: The Discuss List and the U.S. Supreme Court's Agenda-Setting Process." 94(4) Social Science Quarterly 1124.

Brennan, Thomas, Lee Epstein and Nancy Staudt. 2009. "Economics Trends and Judicial Outcomes: A Macrotheory of the Court." 58 Duke L.J. 1191.

Cameron, Charles M. and Lewis A. Kornhauser. 2017. "Rational Choice Attitudinalism? A Review of Epstein, Landes and Posner's The Behavior of Federal Judges: A Theoretical and Empirical Study of Rational Choice" 43 Eur.J. Law and Economics 535.

Cameron, Charles M. and Jee-Kwang Park. 2009. "How Will They Vote? Predicting the Future Behavior of Supreme Court Nominees." 6 J. Empirical Legal Studies 485.

Carroll, Royce and Lydia Tiede. 2011. "Judicial Behavior on the Chilean Constitutional Tribunal." 8(4) $J$. Empirical Legal Studies 856.

Choudhry, Sujit and Claire E. Hunter. 2003. "Measuring Judicial Activism on the Supreme Court of Canada: A Comment on Newfoundland (Treasury Board) v. NAPE.” 48 Mc Gill Law Journal 525.

Clark, Tom S. 2006. "Judicial Decision Making During Wartime." 3 J. Empirical Legal Studies 397.

Clayton, Cornell W. and Howard Gillman. 1999. "Introduction" in Cornell W. Clayton and Howard Gillman, eds., Supreme Court Decision-Making: New Institutionalist Approaches (Chicago: University of Chicago Press.

Cohen, Mathilde. 2014. "Ex Ante Versus Ex Post Deliberations: Two Models of Judicial Deliberation in Courts of Last Resort.” 62 Am. J. Comp. L. 401. 
Cohen, Mathilde. 2016. "The Linguistic Design of Multinational Courts: The French Capture." 14 International J. Const. L. 498.

Cohen-Eliya, Moshe. 2007. "Israel" in Gerhard Robbers, ed., Encyclopedia of World Constitutions, 1st ed. New York: Facts On File.

Collins, Paul M. 2007. "Towards an Integrated Model of the US Supreme Court's Federalism Decision Making." 37(4) Publius J. Fed 505.

Comparative Constitutions Project. 2017. "Constitutions Rankings." Accessed on-line August 2017 at comparativeconstitutionsproject.org/ccp-rankings.

Comparative Constitutions Project. 2017a. "Rights Index." Accessed on-line August 2017 at comparativeconstitutionsproject.org/files/RightsIndex.pdf?6c8912.

Cordray, Richard and Margaret Cordray. 2008. "Strategy in Supreme Court Case Selection: The Relationship between Certiorari and the Merits." 69(1) Ohio State Law Journal 1.

Devins, Neal and Lawrence Baum. 2014. "Split Definitive: How Party Polarization Turned the Supreme Court into a Partisan Court." The Supreme Court Review 2016301.

Edelman, Paul H., David E. Klein and Stefanie A. Lindquist. 2012. "Consensus, Disorder, and Ideology on the Supreme Court." 9 J. Empirical Legal Studies 129.

Eisenberg, Theodore, Talia Fisher and Issi Rosen-Zvi. 2011. "Israel's Supreme Court Appellate Jurisdiction: An Empirical Study." 96 Cornell Law Review 693.

Eisenberg, Theodore, Talia Fisher and Issa Rosen-Zvi. 2012. "Does the Judge Matter? Exploiting Random Assignment on a Court of Last Resort to Assess Judge and Case Selection Effect." $9 J$. Empirical Legal Studies 246.

Elkins, Zachary, Tom Ginsburg \& James Melton. 2009. The Endurance National Constitutions. Cambridge: Cambridge University Press.

Elkins, Zachary, Tom Ginsburg and James Melton. 2012. “Constitutional Constraints on Executive Lawmaking." Working Paper.

Epstein, Lee, Daniel E. Ho, Gary King and Jeffrey Segal. 2005. "The Supreme Court During Crisis: How War Affects Only Non-War Cases.” 80(1) NYU Law Review 1.

Epstein, Lee and Jack Knight. 1998. The Choices Justices Make. Washington, DC: CQ Press.

Epstein, Lee, Jack Knight and O. Shvetsova. 2002. "The Role of Constitutional Courts in the Establishment and Maintenance of Democratic Systems of Government." 35 Law and Society Review 117.

Epstein, Lee, William M. Landes and Adam Liptak. 2015. "The Decision to Depart (or Not) from Constitutional Precedent: An Empirical Study of the Roberts Court." 90 NYU Law Review 1115.

Epstein, Lee, William M. Landes and Richard A. Posner. 2013. The Behavior of Federal Judges: A Theoretical and Empirical Study of Rational Choice (Cambridge, MA: Harvard University Press). 
Epstein, Lee, Andrew D. Martin, Kevin Quinn and Jeffrey A. Segal. Forthcoming. "Politics and the Legal System." In Roger Congleton, Bernard Grofman and Stefan Voight, eds., Oxford Handbook of Public Choice.

Epstein, Lee, Andrew D. Martin and Jeffrey A. Segal. 2012. "Must Grants, Clear Denials and Mid-Level Politics: The First Step Towards a Bounded Discretion Model of Certiorari Decisions." (Paper delivered at the $2^{\text {nd }}$ Annual Conference on Institutions and Law Making).

Epstein, Lee, Andrew D. Martin, Jeffrey A. Segal and Chad Westerland. 2007. "The Judicial Common Space.” 23(2) J. Law, Economics and Organization 303.

Epstein, Lee, Christopher Park and Jeffrey Segal. 2013. "Do Justices Defend the Speech They Hate? Ingroup Bias, Opportunism and the First Amendment." Online: papers.ssrn.com/so13/papers.cfm?abstract_id=2300572.

Fischman, Joshua B. 2015. "Interpreting Circuit Court Patterns: A Social Interactions Framework." 31(4) J. Law, Economics and Organization 808.

Fischman, Joshua B. and David Law. 2009. "What is Judicial Ideology and How Should We Measure It?" 29 Washington U. Journal of Law and Policy 133.

Flemming, Roy and Glen Krutz. 2002. "Selecting Appeals for Judicial Review in Canada: A Replication and Multivariate Test of American Hypotheses." 64(1) J. Politics 232.

Garoupa, Nuno, Fernando Gomez-Pomar and Veronica Grembi. 2013. "Judging Under Political Pressure: An Empirical Analysis of Constitutional Review Voting in the Spanish Constitutional Court." 29(3) $J$. Law, Economics and Organizations 513.

Green, Andrew and Albert Yoon. 2017. "Triaging the Law: Developing the Common Law on the Supreme Court of India." (forthcoming) Journal of Empirical Legal Studies.

Groffman, Bernard and Timothy J. Brazill. 2002. "Identifying the Median Justice on the Supreme Court through Multidimensional Scaling: Analysis of 'Natural Courts'." Kluwer Academic Publishers 55.

Hanretty, Chris. 2012. "Dissent in Iberia: The Ideal Points of Justices on the Spanish and Portuguese Constitutional Tribunals." 51(5) European J. Political Research 671.

Hanretty, Chris. 2013. "The Decisions and Ideal Points of British Law Lords.” 43(3) British J. Political Science 703.

Hansford, Thomas G. and James F. Spriggs II. 2006. The Politics of Precedent on the U.S. Supreme Court. Princeton: Princeton University Press.

Hofnung, Menachem and Keren Weinshall. 2010. "Judicial Setbacks, Material Gains: Terror Litigation at the Israeli High Court of Justice.” 7 J. Empirical Legal Studies 664.

Honnige, Christoph. 2009. "The Electoral Connection: How the Pivotal Judge Affects Oppositional Success at European Constitutional Courts.” 32(5) West European Politics 963. 
Iaryczower, Matias and Gabriel Katz. 2016. "More than Politics: Ability and Ideology in the British Appellate Committee." 32(1) J. Law, Economics and Organization 61.

Iaryczower, Matias and Matthew Shum. 2012. "The Value of Information in the Court: Get it Right, Keep it Tight.” 102(1) American Economic Review 202.

Kastellec, Jonathan P. 2010. "The Statistical Analysis of Judicial Decisions and Legal Ruels with Classification Trees.” 7 J. Empirical Legal Studies 202.

Kastellec, Jonathan P. 2013. "Racial Diversity and Judicial Influence on Appellate Courts." 57(1) American Journal of Political Science 167.

Kritzer, Herbert M. and Mark J. Richards. 2003. "Jurisprudential Regimes and Supreme Court Decision Making: The Lemon Regime and Establishment Clauses Cases.” 37 Law and Society Review 827.

Landes, William M. and Richard A. Posner. 1976. "Legal Precedent: A Theoretical and Empirical Analysis." 19 J. Law and Economics 249.

Law, David S. 2009. "The Anatomy of a Conservative Court: Judicial Review in Japan" 87 Texas Law Review 1545.

Law, David S. 2015. “Judicial Comparativism and Judicial Diplomacy” 163 U. Penn. L. R. 927.

Mate, Manoj. 2015. "The Rise of Judicial Governance in the Supreme Court of India." 33 Boston University International Law Journal 101.

Martin, Andrew and Kevin M. Quinn. 2002. "Dynamic Ideal Point Estimation via Markov Chain Monte Carlo for U.S. Supreme Court 1953-1999.” 10 Political Analysis 134.

McAdams, Richard. 1997. "The Origin, Development, and Regulations of Norms." 96 Michigan Law Review 338.

McClean, David. 2007. "United Kingdom" in Gerhard Robbers, ed., Encyclopedia of World Constitutions, 1st ed. New York: Facts On File.

Melton, James and Tom Ginsburg. 2014. "Does De Jure Judicial Independence Really Matter? A ReEvaluation of Explanations for Judicial Independence." 2(2) J. Law Courts 187.

Narayan, PK and Russel Smyth. 2007. "What Explains Dissent on the High Court of Australia? An Empirical Assessment Using a Cointegration and Error Correction Approach." $4 \mathrm{~J}$. Empirical Legal Studies 401.

Niblett, Anthony and Albert H. Yoon. 2015. "Judicial Disharmony: A Study of Dissent." 42 International Review of Law and Economics 60.

Ostberg, C.L. and Matthew E. Wetstein. 2007. Attitudinal Decision Making in the Supreme Court of Canada. (Vancouver, BC: UBC Press).

Ostberg, C.L. and Matthew E. Wetstein. 2017. Value Change in the Supreme Court of Canada. (Toronto: University of Toronto Press). 
Parker, Christopher M. 2011. "Ideological Voting in Supreme Court Federalism Cases, 1953-2007.” 32(2) Justice System J. 206.

Posner, Richard. 2008. How Judges Think. (Cambridge, MA: Harvard University Press).

Posner, Richard. 2004. "Judicial Behavior and Performance: An Economic Approach." 32 Florida State U. Law Review 1259.

Rachlinski, Jeffrey, Andrew J. Wistrich and Chris Guthrie. 2011. "Probable Cause, Probability, and Hindsight." 8 Journal of Empirical Legal Studies 72.

Rachlinski, Jeffrey, Andrew J. Wistrich and Chris Guthrie. 2015. "Can Judges Make Reliable Numeric Judgments? Distorted Damages and Skewed Sentences.” 90 Indiana Law Journal 695.

Robertson, David. 1998. Judicial Discretion in the House of Lords. New York: Oxford University Press.

Robinson, Nick. 2013. "Structure Matters: The Impact of Court Structure on the Indian and U.S. Supreme Court." 61 American J. Comparative Law 173.

Rothstein, Daniel J. 1985. “Adjudication of Freedom of Expression Cases Under Israel's Unwritten Constitution." 18 Cornell International Law Journal 247.

Rosenfeld, Michel. 2004. "Constitutional Adjudication in Europe and the United States: Paradoxes and Contrasts.” 2 International J. Constitutional Law 633.

Schorpp, Susanne. 2011. The Rule of Law in Times of War: A Comparative Analysis of the Effect of War on High Court Decision-Making. University of South Carolina.

Schwartz, Alex and Melanie Janelle Murchison. 2016. "Judicial Impartiality and Independence in Divided Societies: An Empirical Analysis of the Constitutional Court of Bosnia-Herzegovina." 50(4) Law \& Society Review 822.

Segal, Jeffrey and Albert Cover. 1989. "Ideological Values and the Votes of U.S. Supreme Court Justices.” 83(2) American Political Science Rev. 557.

Segal, Jeffrey A. and Harold J. Spaeth. 2002. The Supreme Court and the Attitudinal Model Revisited (Cambridge: Cambridge University Press).

Sen, Amartya. 2002. Rationality and Freedom. Cambridge, MA: Harvard University Press.

Sen, Amartya. 2009. The Idea of Justice. Cambridge, MA: Harvard University Press.

Sisk, Gregory C., Michael Heise and Andrew P. Morris. 2004. "Searching for the Soul of Judicial Decisionmaking: An Empirical Study of Religious Freedom Decisions.” 65 Ohio State LJ 491.

Sisk, Gregory C. and Michael Heise. 2012. "Ideology All the Way Down? An Empirical Study of Establishment Clause Decisions in the Federal Courts." Online: https://papers.ssrn.com/so13/papers.cfm?abstract-id=1791214.

Sisk, Gregory C. and Michael Heise. 2012. "Muslims and Religious Liberty in the Era of 9/11: Empirical Evidence from the Federal Courts." Online: https://papers.ssrn.com/so13/papers.cfm?abstract_id=1917057. 
Skiple, Jon Kare, Gunnar Grendstad, William R. Shaffer and Eric N. Waltenburg. 2016. "Supreme Court Justice's Economic Behaviour: A Multilevel Model Analysis.” 39(1) Scandinavian Political Studies 73.

Smyth, Russell. 2004. "What Explains Variations in Dissent Rates? Time Series Evidence from the High Court.” 26 Sydney Law Review 221.

Songer, Donald R., Susan Johnson and C.L. Ostberg. 2012. Law, Ideology and Collegiality: Judicial Behaviour in the Supreme Court of Canada. Montreal: McGill-Queen's Press.

Songer, Donald R. and Julia Siripurapu. 2009. "The Unanimous Decisions of the Supreme Court of Canada as a Test of the Attitudinal Model." 42(1) Canadian J. Political Science 65.

Songer, Donald R., John Szmer and Susan W. Johnson. 2011. "Explaining Dissent on the Supreme Court of Canada." 44(2) Canadian Journal of Political Science 389.

Stephenson, Matthew. 2009. "Legal Realism for Economists.” 23 Journal of Economic Perspectives 191.

Sunstein, Cass et al. 2006. Are Judges Political? An Empirical Analysis of the Federal Judiciary. Washington: Brookings Institution Press.

Ulmer, Alexandra and Diego Ore. 2017. "Venezuela's Opposition-Led Congress Names Alternative Supreme Court Judges." Toronto Globe and Mail (July 21, 2017).

Walker, Thomas G., Lee Epstein and William J. Dixon. 1988. "On the Mysterious Demise of Consensual Norms in the United States Supreme Court.” 50(2) J. Politics 361.

Weiden, David. 2011. "Judicial Politicization, Ideology, and Activism at the High Courts of the United States, Canada and Australia." 64(2) Political Research Quarterly 335.

Weingast, Barry. 2002. "Rational-Choice Institutionalism." In Ira Katznelson and Helen Milner, eds., Political Science: The State of the Discipline. New York: Norton.

Weinrib, Lorraine E. 2016. "The Canadian Charter's Override Clause: Lessons for Israel." 49(1) Israel Law Review 67.

Weinshall-Margel, Keren. 2011. "Attitudinal and Neo-Institutional Models of Supreme Court Decision Making: An Empirical and Comparative Perspective from Israel." 8 Journal of Empirical Legal Studies 556.

Weinshall, Keren, Udi Sommer and Ya'acov Ritov. 2017. "Ideological Influences on Governance and Regulation: The Comparative Case of Supreme Courts." Regulation and Governance (forthcoming).

Wetstein, Matthew E., et al. 2009. "Ideological Consistency and Attitudinal Conflict: A Comparative Analysis of the US and Canadian Supreme Court." 42(6) Comparative Political Studies 763. 